\title{
Crashed Electric Vehicle Handling and Recommendations-State of the Art in Germany
}

\author{
Katharina Wöhrl $\mathbb{1}^{\text {, }}$, Christian Geisbauer $(\mathbb{C}$, Christoph Nebl, Susanne Lott and Hans-Georg Schweiger *
}

Technische Hochschule Ingolstadt, CARISSMA Institute of Electric, Connected and Secure Mobility (C-ECOS), Esplanade 10, D-85049 Ingolstadt, Germany; katharina.woehrl@carissma.eu (K.W.);

Christian.Geisbauer@carissma.eu (C.G.); Christoph.Nebl@carissma.eu (C.N.); Susanne.Lott@carissma.eu (S.L.)

* Correspondence: Hans-Georg.Schweiger@thi.de

Citation: Wöhrl, K.; Geisbauer, C.; Nebl, C.; Lott, S.; Schweiger, H.-G. Crashed Electric Vehicle Handling and Recommendations-State of the Art in Germany. Energies 2021, 14, 1040. https://doi.org/10.3390/ en14041040

Academic Editor: Lluc Canals Casals Received: 19 January 2021

Accepted: 10 February 2021

Published: 16 February 2021

Publisher's Note: MDPI stays neutral with regard to jurisdictional clai$\mathrm{ms}$ in published maps and institutional affiliations.

Copyright: (C) 2021 by the authors. Licensee MDPI, Basel, Switzerland. This article is an open access article distributed under the terms and conditions of the Creative Commons Attribution (CC BY) license (https:// creativecommons.org/licenses/by/ $4.0 /)$.

\begin{abstract}
In the near future, electric powered vehicles will represent a major part of the road traffic. Accordingly, there will be a natural increase of accidents involving electric vehicles. There are not many cases of such accidents yet and therefore the experience and correct handling are still partially open points for the involved parties, such as the rescue services for example. The aim of this work is to provide a complete overview of the accident handling sequence in Germany, starting with the damaged vehicle on site and moving on to the risks and challenges for the stakeholders, such as transport and recycling companies. Arising from the developed overview, a handling recommendation for yet undiscussed points is given. Especially, different extinguishing and deactivation methods are compared and discussed. Due to a lack of a common live-feed from battery data on site, other criteria have to be taken into account to assess the state of the battery. The wrecked vehicle-including the high voltage system - needs to be in a definite safe state at the handover to a towing service. Depending on the case, different options for securing the vehicle will be considered in this work.
\end{abstract}

Keywords: electric vehicle; battery; high voltage; accident; recommendation; energy storage; thermal runaway; fire extinguishing; rescue service; handling

\section{Introduction}

Electric powered devices become even more important in our everyday life. From smartphones, laptops, power tools, to electrically propelled scooters and road vehicles, many of them have lithium ion batteries as their power source. Key advantages of lithium ion batteries $(\mathrm{LiB})$ are their long life expectancy, high power, and energy density and low self-discharge rates [1,2]. Therefore, they are nowadays a common energy storage solution for propelling electric and hybrid electric road vehicles.

Powered solely by renewables, electric vehicles (EV) emit no carbon dioxide during their operation and thus can help to tackle the worldwide problem of global $\mathrm{CO}_{2}$ emissions. To achieve this, limits and targets for the $\mathrm{CO}_{2}$ reduction have been defined [3]. In the year 2018, electricity production, heat generation, transport and industrial applications were the main contributors to the global $\mathrm{CO}_{2}$ footprint [4]. The impact of the transport sector on the total emissions is not negligible, as in 2018 the percentage of this category accounts for $25 \%$ of the global $\mathrm{CO}_{2}$ emissions [4]. Starting from January 2020, regulations of the European Union (EU) set a fleet-wide average emission target for new registered passenger cars to $95 \mathrm{~g} \mathrm{CO}_{2} / \mathrm{km}$ [3]. This limit will be further reduced by $37.5 \%$ to 2030 [5]. Therefore, the governments and industries are pushing towards vehicles with less carbon emissions such as EVs [3]. Consequently, an increase in registered EVs from 2013 to 2019 was recorded as about a factor of 10 in Germany [6]. Thus, a clear upward trend in new registrations can be identified, so a natural increase in vehicle accidents involving EVs will occur.

In this work, 'crash' and 'accident' are defined as a sudden, unexpected event that leads to either property damage or lethal consequences. For more severe cases, the event will trigger the airbag control unit and prepare the vehicle and its occupants for impact. 
Serious accidents at high speeds can result in heavy consequences for the high voltage system of the vehicle, leading to possible dangers such as electric shock, for the vehicle occupants and for rescue services.

In the automotive sector the high-voltage range is defined from $>60 \mathrm{~V}$ to $\leq 1500 \mathrm{~V}$ (DC) and $>30 \mathrm{~V}$ to $\leq 1000 \mathrm{~V}$ (AC) [7-9]. Electric vehicles are mostly equipped with traction systems below these maximum voltage limits, as it would involve additional costs for reinforced insulation to ensure a safe battery and traction system. A current trend for automotive manufacturer is, to increase system level from $400 \mathrm{~V}$ up to $800 \mathrm{~V}$ as this would lower the current draw for driving and charging and enable even higher charging power. Two present examples for this case would be Porsche's Taycan 4S [10] and Hyundai's Ioniq 5 [11]. This voltage increase calls for more safety margins for example air and creepage distance.

Due to mechanical deformations of the vehicle during an accident, the risk of damaging the high voltage traction battery is given. The cells of the battery can be exposed to a situation outside of the defined working range. This situation can lead to mechanical, thermal, or electrical abuse conditions [12], which again lead to strongly rising temperatures and self-heating rates (SHR) of the cells further amplifying the severity of the situation. This temperature rise accelerates the unwanted chemical reactions in the cells, resulting in even higher temperatures and leading to an unstoppable self-reinforcing process. If one of the cells enters thermal runaway (TR) stage, the risk of thermal propagation towards the whole module and maybe even the whole traction battery in an electric or hybrid electric vehicle (HEV) is not to be underestimated when assessing safety hazards $[13,14]$.

The intention of this work is to show the actual accident management procedure of damaged electric vehicles in Germany. Until now, only few accidents with electric vehicles are recorded, so naturally an uncertainty for rescue services is present at this stage. This fact is demonstrated by the example of a burning electric vehicle in Austria in 2019. The responsibilities were not clarified and therefore the proceeding steps regarding towing and recycling were difficult to organize [15]. Arising from the elaborated procedures in this work, recommendations for the rescue services and additional involved parties are suggested with the main goal of shedding light onto a rather new territory.

\section{Technical and Human Aspects Related to Safety}

\subsection{Safety Requirements for Electric or Hybrid Electric Vehicles}

To ensure safety during operation and even in the event of a road accident, every car is designed to fulfil general safety requirements. This applies to vehicles with combustion engine as well as full or partially electric propelled vehicles.

Prior to vehicle type approval for public roads in the EU, implementation of the requirements specified by the United Nations Economic Commission for Europe (UNECE) must be performed. Requirements as requested in UNECE Global Technical Regulation (GTR) 20 for electric vehicle safety [16], UNECE R94 for frontal crash [17], UNECE R95 for side impact [18], UNECE R100 [9], or UNECE R135 for side collision with pole impact [19] serve the purpose of minimizing risks for vehicle occupants during crashes. Every crash scenario contains specific requirements for each vehicle type. Those requirements are identical for internal combustion engine (ICE) cars and vehicles equipped with an electric motor. However, there are additional requirements for EVs that refer to the safety of rechargeable energy storage systems (REESS). UNECE R100 includes abusive tests for the high voltage battery, such as mechanical stress, fire resistance, external short circuit, overcharge, and overheating protection [9]. These tests have to be passed to obtain a road approval.

Every electric vehicle possesses a galvanic separation between the high voltage system and the vehicle ground/chassis. This network structure is called IT (French: Isolé Terre) system. Therefore, touching only one battery pole does not directly lead to an electric shock, because the electric circuit is not closed. 
Additional precautions in EVs are interlock mechanisms, galvanic isolation between high voltage parts, correct air and creepage distances between conductive parts, insulation resistance monitoring, electric arc resistant connectors, high voltage warning labels, and orange colored cables for high voltage components [8]. Furthermore, there are post-crash criteria such as forbidden mounting zones for the REESS, underbody protection, and precautionary measures in case of toxic electrolyte leakage [16].

Requirements such as low State of Charge (SoC) warning, information about the driving status of the vehicle and warning in case of thermal event are part of the functional safety requirements of the vehicle.

The REESS represents the main potential source of danger, especially in the case of an accident. The hazard of potential electric shock is reduced by following dedicated requirements mentioned earlier [9,16-18]. Starting with the detection of a crash, the high voltage traction system must be discharged within $5 \mathrm{~s}[17,18]$.

The requirements make demand to achieve at least one of the four criteria after a crash $[17,18]$ :

- $\quad$ Reduction of the high voltage on electric interfaces to: $\mathrm{U}_{\mathrm{DC}}<60 \mathrm{~V} ; \mathrm{U}_{\mathrm{AC}}<30 \mathrm{~V}$ within 5 s;

- Reduction of electrical energy on high voltage bus bars: $\mathrm{E}_{\text {total }}<2 \mathrm{~J}$ after $5 \mathrm{~s}$;

- Insulation resistance high voltage-conductors and chassis-mass: >100 $\Omega / V(D C)$; $>500 \Omega / \mathrm{V}(\mathrm{AC})$ after $5 \mathrm{~s}$;

- $\quad$ Ingress protection (IP) class: protection of all live parts from contact by finger (IPXXB).

Furthermore, during or after an impact, the high voltage storage must stay at its installed location. No parts of the battery shall get in the passenger interior. It is not permitted that any components of the battery leave its housing $[17,18]$. Therefore, it can be assumed that none of these components is spread around the accident location.

Up to $30 \mathrm{~min}$ after an accident, no electrolyte from the energy storage must enter the passenger compartment. In addition, no more than $7 \%$ of the battery's electrolyte shall leak out, except from open batteries located outside the passenger compartment, such as the starter battery for ICEs $[17,18]$.

\subsection{Risk Analysis for Rescue Services}

The risks during an EV rescue mission are divided into three groups, electrical, thermal, and chemical. When the vehicle's contactors switch off the high voltage system-due to the triggering of the airbag [20] or the crash sensors in case of accident-the high voltage battery is disconnected from the traction system by opening its main contactors. By deactivation measures, such as discharging the DC-link capacitor of the inverter with a dedicated resistor and by short-circuiting the rotor of the electric machine, the vehicle itself is not dangerous from an electrical perspective. As the vehicle has no common ground potential (IT system) with the high voltage system, the risk of electric shock is reduced. However, coming into direct contact with either both battery poles or a single battery pole and partially short-circuited cells, it can still lead to hazards such as electric shock or arcing, because of closing the electric circuit. The battery discharges itself with a short circuit if there is no fuse is in between. This can lead to fatal consequences and fire. Therefore, it is important that the rescue team and all involved parties keep a safe distance from conducting parts like orange cables or the traction battery itself. Generally, there are no clear indicators for absence of voltage. Therefore, the manual deactivation of the high voltage system must be carried out in reference to the rescue data sheet [20] of the vehicle.

Thermal risks can arise electrically from high short circuit currents, chemically from the energy stored in the cells or externally from a fire or contact with other hot components. If the cell temperature increases above of the maximum operating range, exothermic reactions can take place in the cells. Spotnitz et al. [13] describes the ongoing processes inside lithium batteries during these exothermic reactions in detail. The layer on the negative electrode, referred to as the solid electrolyte interface (SEI), is metastable and breaks down at 90-120 ${ }^{\circ} \mathrm{C}$. When the SEI is broken $\left(>120{ }^{\circ} \mathrm{C}\right)$, the anode is exposed to the electrolyte. Therefore, reactions between the anode with its intercalated lithium and the electrolyte occur [13]. The 
next exothermal process is the breakdown of the separator. Depending on the composition of the separator, the breakdown temperature differs. A polyethylene (PE)-polypropylene (PP) separator for example melts at $165{ }^{\circ} \mathrm{C}$ [21]. When reaching temperatures above $200{ }^{\circ} \mathrm{C}$, the electrolyte decomposes. Depending on the cathode material, the decomposition temperatures of the positive electrode vary. During this disintegrating process, the cathode releases its own oxygen and thus reacts violently with the electrolyte of the battery [13]. Those reactions represent the thermal runaway process.

Additionally, the heating can lead to fire, flares and sparks. In combination with a combustible gas-air mixture from a venting cell and an ignition source-i.e., sparks-the ignition can result in an explosion [22]. The actual temperatures and their corresponding reactions depend on many factors, like the cell type [23] and the state of health [24]. The appearance of a thermal runaway can occur right away after an accident, delayed or not at all-depending on the state of damage of the high voltage battery $[25,26]$. Especially the second and third case are more difficult to evaluate. From the past, we know the incident with the range extended electric vehicle Chevrolet Volt from General Motors. A side-crash abuse test was carried out which was successfully completed for the first moment. However, this crash had delayed consequences. Three weeks after the test, the battery shorted itself and caught fire [27,28].

During a fire experiment conducted by NFPA (National Fire Protection Association) with a LiB test system (80 Ah) [29,30], the inner temperatures of several hundred degrees can lead to injuries and even ignite objects in a small radius around the system. The time required to extinguish the source of battery fire may exceed the oxygen supply time of the firefighters $[29,30]$. By extinguishing the burning battery from a safe distance and utilizing spray jet ( $1 \mathrm{~m}$ distance between the firefighter and the fire source) or full jet ( $5 \mathrm{~m}$ gap), the dangers can be minimized [31].

The third category represents chemical hazards that arise from the release of pollutants or harmful and caustic substances from the cells. In addition, flammable and corrosive electrolyte in gaseous and liquid form may leak and ignite [20].

The electrolyte solutions of LiBs consists of electrolyte salts, organic carbonates as solvent, and additives [32]. Lithium hexafluorophosphate $\left(\mathrm{LiPF}_{6}\right)$ [33] and lithium tetra fluoroborate $\left(\mathrm{LiBF}_{4}\right)$ are mainly used as the salt in the electrolyte solution. The anion hexafluorophosphate $\left(\mathrm{PF}_{6}^{-}\right)$enables high cell voltages and long-term stability of the battery [34]. However, reacting with water or humid air, $\mathrm{PF}_{6}^{-}$disintegrates into toxic $\mathrm{HF}$ (hydrofluoric acid) as shown in the following equations [34,35]:

$$
\begin{gathered}
\mathrm{LiPF}_{6} \rightarrow \mathrm{LiF}+\mathrm{PF}_{5} \\
\mathrm{PF}_{5}+\mathrm{H}_{2} \mathrm{O} \rightarrow \mathrm{POF}_{3}+2 \mathrm{HF}, \\
\mathrm{LiPF}_{6}+\mathrm{H}_{2} \mathrm{O} \rightarrow \mathrm{LiF}+\mathrm{POF}_{3}+2 \mathrm{HF},
\end{gathered}
$$

a similar reaction occurs if $\mathrm{LiBF}_{4}$ is used as conductive salt [36]:

$$
\begin{gathered}
\mathrm{LiBF}_{4} \rightarrow \mathrm{BF}_{3}+\mathrm{LiF} \\
\mathrm{BF}_{3}+\mathrm{H}_{2} \mathrm{O} \rightarrow \mathrm{BF}_{2} \mathrm{OH}+\mathrm{HF},
\end{gathered}
$$

due to this aspect, it is important that the cell is completely tight and impermeable to air [34]. A possible crash consequence could be the deformation of the high voltage battery system, its modules and even cells, leading to leakage and intrusion of water and air into the cell, resulting in HF formation.

$\mathrm{HF}$ is an extremely dangerous substance as it is very toxic, corrosive, highly reactive, and causes serious health damage or even fatal consequences. Molecular HF is liquid between $-83^{\circ} \mathrm{C}$ and $20^{\circ} \mathrm{C}$ at $1013 \mathrm{hPa}$ and above this temperature in a gaseous state [37]. The exact values are dependent of the actual HF concentration and may vary [38]. Direct contact with HF can lead to skin burns and damage deeper skin layers [39,40]. Even small amounts can result in painful burns. If eyes come into direct contact with $\mathrm{HF}$, pain, 
irritations or serious injury can be caused [41]. A further negative aspect is the inhalation of HF fumes or vapors [37], as small amounts of HF can lead to heavy respiratory damage, nose, lungs, or throat irritation. When HF is splashed onto clothing, it can be inhaled on a later stage and this may lead to serious consequences [42]. Generally, contact with diluted solutions of HF can stay unnoticed for a while, resulting in delayed countermeasures and delayed toxicity $[39,41]$. To protect the rescue team from those hazards, the firefighters protective equipment is highly significant for working close to electrical vehicles in an unpredictable state. The complete personal protective equipment (PPE) should be resistant to chemicals, heat and flames [43]. Combined with a safety helmet, visor, respirator mask, oxygen tank, gloves, leather shoes of security class S3 and special harness, a full protection can be achieved $[43,44]$.

For humans, inhaling a dose of $50 \mathrm{ppm}$ HF for $30 \mathrm{~min}$ can have lethal consequences [45]. The Occupational Safety and Health Administration (OSHA) limits the maximum exposure time at the workplace $(8 \mathrm{~h})$ to 3 ppm [45]. Qiao et al. [40] investigate the release and toxicity of the separator, drenched with electrolyte, a main source of HF. They showed that the release of $\mathrm{HF}$ of a $1 \mathrm{~g}$ sample from a burning separator, which was removed from a $\mathrm{LiFePO}_{4}$ cell with $25 \mathrm{Ah}$, correlates to the state of health $(\mathrm{SoH})$ of the cell. The $1 \mathrm{~g}$ burned separator emits 96.496 ppm and 41.94 ppm HF in a measured $20 \mathrm{~L}$ air volume at $100 \% \mathrm{SoH}$ and $65 \%$ respectively, showing a decrease in HF release for cells with lower SoH. This demonstrates that lithium ion cells in theory can produce critical amounts of HF for humans.

In order to correlate the chemical hazards emerging from electric and conventional vehicles, total emissions during fire need to be evaluated. Lecocq et al. [46] investigated and compared the generated amount of HF and other ejected gases for burning EVs and ICE vehicles by using online gas analysis and a FTIR (Fourier transformation infrared spectroscopy) setup. The experiment was carried out in a ventilated area and repeated twice. The left front seat in the passenger compartment was ignited with a gas burner. A particularly interesting finding is the released amount of $\mathrm{HF}$, as both vehicle types produce a significant amount while burning. Both test subjects show a steep rise of emitted HF 14 min after the ignition. Additionally, the EV has other emission peaks 25-30 min into the experiment, as the high voltage battery combustion begins. These HF peaks can be traced back to the fluoride-containing compounds like the conducting salt $\mathrm{LiPF}_{6}$ and binder materials [46].

Although the ICE vehicle has no LiB on board, there was a noteworthy amount of HF in total. It is suspected that fluoride-containing components from the coolant of the air conditioning system (e.g., R1234yf [47]) was responsible for the first peak of HF for both types [46]. In direct comparison, the amount of produced HF is twice as much for EVs as for ICE vehicles in this investigated case. Other gases like $\mathrm{CO}_{2}, \mathrm{CO}, \mathrm{NO}, \mathrm{NO}_{2}, \mathrm{HCl}, \mathrm{HCN}$, and hydrocarbons are about the same amount for both vehicle types [46].

\section{General Procedures for Traffic Accidents with EVs}

In the following paragraphs the rescue sequence-starting from the emergency call and ending with the recycling process-in Germany is described.

\subsection{Incoming Emergency Call in Control Center}

After a vehicle has crashed and the occupants are in distress, it is mandatory for every citizen in Germany to provide first aid [48]. An important part of first aid is, to send out an emergency call to inform the rescue services. The Regulation 2015/758 of the European Parliament requires the deployment of the emergency call (short eCall) in-vehicle system based on the 112 service [49]. Since 2018, it is obligatory for car manufacturers to equip all new vehicles with this automated eCall system in Europe. The aim is to reduce fatalities, by automatically alerting the rescue services prematurely $[49,50]$.

It is possible to trigger the eCall manually by pushing the emergency button in the car. However, the big novelty is that the call for help will be sent out automatically, when the vehicle's internal sensors, especially those that also trigger the airbags, are activated in 
the event of an accident $[43,50]$. Now the vehicle's internal minimum set of data (MSD), defined in DIN EN 15722, will be transmitted via mobile phone network to the responsible contact point within a few tens of seconds [50].

Depending on the manufacturer choice, the eCall will be transferred either directly to the local public safety answering point (PSAP) or to a third-party service provider (TPSP), which then contacts the responsible PSAP [49,51]. After successful reception of the MSD, an audio connection with the vehicle will be established. If the occupants are responsive, they will be contacted in their mother tongue, even if the accident-damaged vehicle is located in European outside the native country [51]. The language of the eCall is based on the entertainment language setting of the car.

The structure, distribution and content of the transferred minimum set of data [50] is shown in Figure 1. Data is divided into a block with standard information and an optional data block. The first one contains defined information about the vehicle, such as the last two positions with coordinates, the vehicle identification number and the kind of energy storage - such as diesel, hydrogen, or electric. The optional data block has a maximum byte length of 94 bytes and can be freely designed by the manufacturer. The total length of both blocks are limited to 140 bytes [50,52]. Everything beyond this maximum length will be ignored by the receiving unit [50].

\begin{tabular}{|c|c|}
\hline maximum length of 46 bytes & maximum length of 94 bytes \\
\hline Standard information block & Optional data block \\
\hline $\begin{array}{ll}- & \text { Automatic or manual activation } \\
- & \text { Testcall (yes/no) } \\
- & \text { Position confidentiality } \\
- & \text { Vehicle type } \\
\text { - } & \text { Vehicle identification number } \\
\text { - } & \text { Vehicle energy storage type } \\
- & \text { Time stamp } \\
- & \text { Vehicle position } \\
- & \text { Direction of travel } \\
- & \text { Last vehicle position (optional) } \\
- & \text { Number of occupants (optional) }\end{array}$ & Freely assignable by manufacturers \\
\hline
\end{tabular}

Figure 1. Emergency call content and defined byte length according to DIN EN 15722 [50].

If necessary, the minimum set of data can be requested again by the PSAP [50,52]. A message ID counts the numbers of all incoming MSDs [50]. The content of the incoming messages is updated.

The task of the public safety answering point is the alerting and coordinating of the emergency rescue services. The information received from the eCall will be transmitted to the firefighters via radio messages $[53,54]$.

Only a defined time span may elapse between reception of the call and the initiation of assistance measures by the rescue forces at the scene of the accident. In Germany, this period of assistance varies depending on the laws of the federal states [55]. It may range from $5 \mathrm{~min}$ in easily accessible locations to $20 \mathrm{~min}$ in rural areas [56].

Since 2013, it is possible for the PSAP to conduct a real-time license plate retrieval at the Federal Motor Transport Authority (Kraftfahrtbundesamt) in Germany. A special software for this query is required [43,57]. SilverDAT [58] and Crash Recovery System [59] are currently the two most common software solutions in the German market [43]. Hence, information about the vehicle type and the corresponding rescue data sheet for the crashed vehicle can be obtained [43]. This structured sheet contains the vehicle's most relevant information, for instance the location of the high voltage battery, high voltage cables, airbags, intersection points, as well as a description for deactivating the high voltage system [43]. The rescue sheet usually is sent by e-mail to the firefighters prior to arrival at 
the accident site and can be accessed via phone or tablet. At best, they are already informed about the powertrain in advance.

\subsection{Rescue Service Arrival at Accident Site}

Figure 2 displays the tasks and processes for the rescue service on their way to and at the accident location. The tasks are based on the rescue guideline created by the association of the automotive industry Germany [20,43] and are further explained in this work. The presented guideline assumes a worst-case scenario with a vehicle fire. If no fire occurs, some steps may be partially skipped.

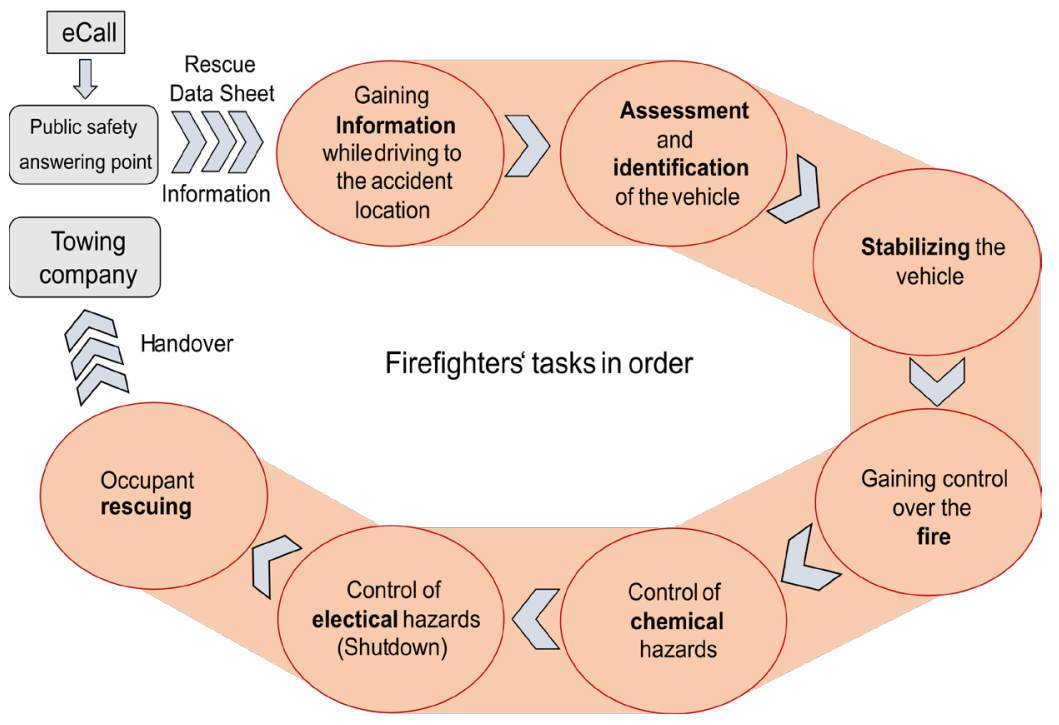

Figure 2. Rescue guidelines for firefighters arriving at the scene of accident in Germany [20,43].

The guideline in Figure 2 begins with the abovementioned reception of the emergency call by the PSAP. The transmission of the main information and the corresponding rescue data sheet to the firefighters are important facts and support them already on the way to the accident location. The actual exploration and identification of the vehicle on site is used to get an overview of the situation. Before the firefighters start with their actual measures, the vehicle has to be brought into a fixed position. As soon as it is secured against rolling away, the firefighting can begin, followed by the control of chemical and electrical hazards. After the risks for the rescue team are eliminated, life saving measures can be initiated. Finally, the handover of the uncritically assessed vehicle to the informed towing company has to be organized to clean up the accident site.

\subsubsection{Identification of the Vehicle}

The distinction between crashed vehicles with combustion engine and those with battery storage, such as hybrid or fully electric vehicles, is a main fact for the whole rescue mission, as different measures need to be undertaken. In the field, it is not always easy to identify the powertrain type at first sight. Distinctive features like high voltage warning labels, specific manufacturer's names and unique design elements, charging port, no exhaust system, charge or status display in the instrument cluster or orange high voltage cables are indicative of an electric powertrain [43,57]. Although caution is advised, because one missing criterion does not necessarily imply that the given vehicle is not electric.

The license plate itself is not a definite and reliable identifier in Germany, because $\S$ 2-4 of Germanys electromobility law [60] state, what kind of vehicle is authorized for using a characteristic ' $E$ ' at the end of the license plate. In this definition, not only battery electric vehicles (BEVs), but also plug-in hybrid electric vehicles (PHEVs) and fuel cell vehicles are listed. Only PHEVs that achieve a minimum electric range of at least $40 \mathrm{~km}$ or emit a maximum of $50 \mathrm{~g} \mathrm{CO}_{2} / \mathrm{km}$ may receive an ' $\mathrm{E}$ '. Additionally, it is up to the vehicle's owner, 
whether this ' $\mathrm{E}$ ' is placed on it or not [60]. Therefore, an EV may not have this characterized ' $E$ ', although it has an on-board high voltage energy storage.

In January 2018, almost $57 \%$ of the previously mentioned electric vehicles are equipped with an 'E' on their license plate [60]. Those car owners are met with advantages, such as tax exemption for 10 years and special parking spots [60]. Therefore, it can be assumed that the proportion of unique registration numbers will increase in the future. Even if the number of ' $\mathrm{E}$ ' plates increases, it is still not possible to achieve a $100 \%$ quota, as not all vehicles with a high voltage storage system meet the requirements of the EmoG [60].

\subsubsection{Accident Categories and Recommendations for Action}

Traffic accidents can vary drastically and the rescue service needs to be prepared for any of them. In Germany, accident researchers divide traffic accidents into six categories. The first three refer to accidents with personal injury, such as accidents involving fatalities, serious or minor injuries. Categories four to six regard property damage, differentiating between the severity of the damage and the influence of alcohol or other intoxicating substances [61].

Beside this already existing categorization, a new possible categorization specifically tailored to accidents involving electric vehicles is introduced in this work. The subdivision does not specifically refer to personal injury or the influence of alcohol, but to the actual state of the damaged vehicle and especially of the high voltage battery. It is necessary to distinguish between cases with occurrence of fire and cases without. Depending on the scene, actions of the emergency services and the arising hazards will be considered.

Figure 3 illustrates the developed scheme of the occurring states of the crashed EV and the involvement of the rescue team. This overview does not consider the human rescue aspect, it can be expected that this process takes place simultaneously to the firefighting. The focus is to get the fire under control and to bring the vehicle into a safe state. After the arrival of the fire brigade, the situation needs to be assessed at first glance. The three possible vehicle states are no fire (NF), smoke emissions (S), and fire (F). This and further definitions are used to describe the occurring states emerging from an electric vehicle fire as seen in Figure 3.

The occurrence of smoke naturally leads to the conclusion that developing flames are imminent. This change of state towards the fire section is shown in Figure 3.

In general, the first task for the rescue team is to observe the vehicle and its behavior. If the vehicle is burning, this phase is altered slightly. For state $\mathrm{F}$, an already ongoing fire, the origin of fire needs to be determined. Whereas the observation period in state NF, no fire, is used to determine the condition of the high voltage battery. Both observation phases are explained below in detail.

As a result, four further states of battery and vehicle conditions can be derived. For the first state, no fire and battery safe (NF-S), the wrecked vehicle can be directly transferred to the second responders. If the battery is damaged and is in a critical status (NF-D), where a consequent fire is expected, but there is no fire yet, it is advised to cool the battery prophylactically from the outside. If the battery is damaged and there is a fire (F-D) the thermal runaway of a single cell can lead to a full battery fire due to thermal propagation between the cells. If this event started, it is difficult to fight against the rapid exothermal reaction. Cooling the system is an effective way to stop the heat propagation between the cells [29] and to reduce the amount of affected cells.

If the vehicle is burning, but the high voltage battery is not yet involved in this active fire (F-ND), conventional extinguishing methods can be used. It is important, to isolate the fire from the traction battery to avoid greater damage by fire propagation to the battery and to continue monitoring the battery.

Observation Period of the not Burning Battery (NF)

In order to gain control over the battery, it is mandatory to keep the system under surveillance. A damaged high voltage battery is the main source of danger, but firefighters do not have direct access to the actual data from the battery management system (BMS) [62]. 
Therefore, they cannot determine the actual state in a reliable way. Only external assessment is possible.

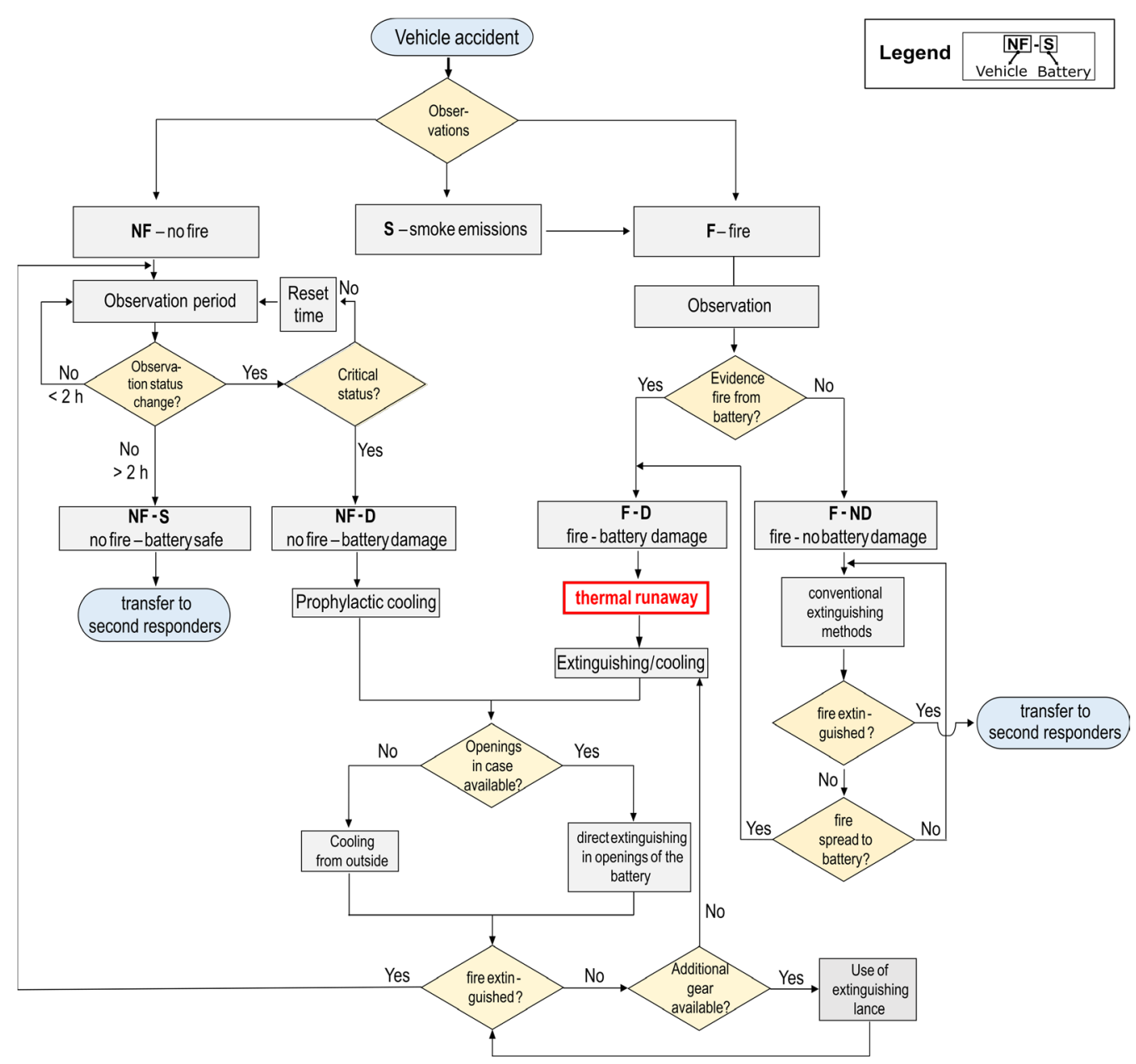

Figure 3. Accident categories of electric vehicles, recommended measures and the potential risk of thermal runaway, dividing possible states of no fire (NF), smoke emissions (S), and fire (F) plus further subdivided states referring to the actual state of the high voltage battery.

However, for a successful verification of the battery state, certain key parameters have to be obtained. Following methods are proposed:

(1) Optical analysis: The visual impression of the vehicle will be the first indicator for firefighters, as they arrive at the scene. After the vehicle is successfully identified as an EV, optical inspection of the traction system is required. The rescue team needs to pay specific attention to the deformation of the battery case, leakage of liquids like electrolyte or coolant, rupture, and smoke generation [63]. A typical indicator for a reactive battery storage is the changing smoke color from black to white. Burning graphite is usually characterized by grey smoke. White smoke can be an indicator for an ongoing fire of electrolyte inside the cells $[29,64]$;

(2) Acoustic analysis: Due to the pressure build up inside the cell housing, caused by heat generation or mechanical deformation, the gas will be released at designated vent openings if the pressure exceeds a certain limit. The audible consequences are hissing and crackling for pouch and prismatic cells, as well as deflagration for cylindrical cells [65];

(3) Gas analysis: The first impression of a ruptured traction system would be a sweet solvent-like odor, typical for leaking electrolyte [65]. In addition, portable gas detection systems can be used to obtain information about the released gases; 
(4) Thermal analysis: The temperature of a lithium ion cell is a good indicator for its state in regard of safety $[24,66]$. Two opportunities to measure the temperature would be directly attached thermocouples or an infrared (IR) camera. The use of an IR camera is problematic: the purchase costs are not to be underestimated, there is little space below the underbody of the vehicle where the energy storage is typically installed. The metal surfaces of the case reflect other light sources and so falsify the result. Another difficulty that also affects the thermocouple method is the delay and temperature drop of the reading, due to thermal resistance between the measurement points and the actual temperature inside the cell. A possible suggestion would be a combination of both methods. For measurement of the temperature with an IR camera from a distance, attention must be paid to a proper camera setup and to focusing on a non-reflecting surface of the battery. This can be supported by a direct temperature measurement with thermocouples attached to the battery in close proximity to the cells. Both readings should be checked against each other for plausibility.

If any of the mentioned parameters shows a change in value towards a more dangerous direction (e.g., temperature increase), the waiting period in state NF (Figure 3) needs to be reset to zero. The exact duration is not easy to determine, Tesla-for example-recommends a waiting phase of one hour where no fire, smoke, or heat is noticeable. Only then, Tesla endorses the handover to the second responders such as police or vehicle transporters [67]. Depending on the case and the circumstances, the undefined critical state of the energy storage may take more time than one hour, so an observation time of at least $2 \mathrm{~h}$ is advised. This $2 \mathrm{~h}$ timespan is double of the amount of Tesla's recommendation and increases the overall safety while keeping the possible obstruction of traffic as minimal as necessary.

If the battery enters a critical status, prophylactic measures need to be undertaken, as shown in Figure 3.

Critical Status of the Battery

To determine an exact tipping point, coming from a still safe battery system to an unsafe condition, is hard to achieve without internal battery data. The just mentioned clues regarding the optical (1), acoustic (2), odor (3), or thermal (4) analysis methods can be used to point out the signs with the goal of avoiding a thermal runaway. When one of the characteristics of (1)-(3) are met, the shift of the risk evaluation towards critical status is suggested. Category (4) does not deliver a clear indication for critical status. The thermal resistance between cell, outer battery hull and oftentimes even vehicle underbody varies from manufacturer to manufacturer. Therefore, no specific temperature can be derived as maximum temperature. As the parasitic side reactions inside the cell take place even at temperatures as low as $90^{\circ} \mathrm{C}$ [13], temperatures below this value on the underbody might hint to already ongoing exothermal reactions. In order to give clear recommendations, absolute values need to be obtained with experimental data in future investigations.

Observation Period F-Vehicle Already on Fire

If the wrecked automobile is already on fire, the focus is to locate the source of fire. Figure 3 distinguishes between two cases. On the one hand, the battery itself is damaged and on fire (F-D) and on the other hand, the battery is undamaged and not yet involved in the ongoing vehicle fire (F-ND).

The first case can lead to thermal runaway, therefore cooling of the whole battery is advised as the subsequent act to avoid greater damage.

With the assumption in the second case that the battery is not involved in the vehicle fire, the monitoring of the parameters is also recommended, so a spread from the rest of the vehicle over to the battery will be noticed and avoided. To get this fire under control, conventional extinguishing methods are performed.

Gaining Control over the Battery Fire (F-D)

Cooling is the best way to extinguish a battery fire. In order to guarantee safe performance over the full lifetime of a vehicle, all components, e.g., the high voltage components of traction battery system that could be exposed to the environment are sealed. By cooling a battery fire from the outside, the cells as the actual source of the fire (state F-D), are not 
exposed to water. In case of an opening in the battery housing caused by an accident, Tesla and Audi for example recommend using this opening to discharge water directly into the inside of the battery $[67,68]$. A visible flame exit point at the battery housing indicates an opening [65].

An insulated extinguishing lance can be used to pump water into the battery system. However, the impact of the lance can cause an electrical short circuit in the battery system [69]. According to the lance manufacturer, the tool should be used to puncture the battery system housing at an appropriate location given in the rescue data sheet [70]. Usually, it is hit in the in the rear passenger cabin floor from above. Because the sidewalls and bottom of the battery system housing are more stable than its cover [69]. However, in some cases there is no designated puncture location given $[67,68,71-73]$ and by pushing the lance through the battery housing at a wrong place, the potential risk of damaging intact cells and causing an additional hazard is very likely. Some car manufacturers use high-strength steel for their battery housing, so the extinguishing lance cannot be applied. In general, the use of this lance requires a well-founded knowledge of the rescue team on each individual vehicle. The lance should not be used prior to any fire hazards arising from the battery system, as it may start such uncontrolled exothermic reactions instead of preventing them [69].

After the fire is extinguished, the burnt-out vehicle still has to be monitored. Even if the battery seems undamaged from the outside, there is still a possibility that chemical reactions inside the battery cells can lead to a fire once again $[30,74]$. It is very important to use as much water as possible for cooling the battery in order to lower the temperature and therefore the risk for thermal propagation to other cells. The amount of water required for extinguishing an EV fire differs greatly in comparison with an ICE vehicle fire [30]. EV fires require more water to be put out than ICE vehicle fires [75], resulting in a total usage of up to $9.8-11.4 \mathrm{~m}^{3}$ for an EV fire $[67,76]$.

Tap water is primarily used for this purpose, as it is easily accessible. Water and water mist have good properties for fighting LiB fires. Water mist has a good cooling effect and cleans the air by binding fume particles and hydrofluoric acid (HF) in the smoke [35]. An admixture of F 500 microcapsules material in the extinguishing water can lower the extinguishing time and the water consumption and additionally prevents the fire from flaring up again. Using F 500 can result in reduced surface water tension and can form smaller water droplets, which can easier enter the interior of the battery [29].

If the situation after the battery fire is still classified as critical, the deployment of an extinguishing container may be useful. The container serves the purpose of isolating the battery from the surroundings and preventing leakage into the ground. Therefore, the container has a positive environmental aspect, as it collects water contaminated with battery cell components-e.g., electrode particles or electrolyte. During an extinguishing operation, water is usually spilled everywhere around the accident location. This liquid then drains into the ground, as the main focus of the firefighters is stopping the fire and eco-friendly aspects are just secondary thoughts at that point. This problem can be minimized by the use of a container, because then only the precooling step takes part in an open area, whereas on a later stage the water will be collected. Additionally, flooding the container with water can shut down the thermal activity of the vehicle directly at the scene of the accident or at the place of storage. Although, the second option should be favored, as a transport of a completely filled container is more difficult to execute due to the additional weight.

\subsection{Towing from the Accident Site}

The arriving police redirects traffic, records the cause of accident and secures evidence at the accident location [62]. Police is notified about the traction type of the vehicle from the firefighters. It is mandatory for the police to mention this information while commissioning the towing company. Only then, the towing company can send out a qualified person that is trained to deal with damaged electric vehicles [62]. In Germany, qualification for working with high voltage systems is necessary according to DGUV Information 8686 [8,77]. Before 
recovering and towing the damaged EV, the high voltage system should be deactivated [20] and the car shall not be in critical condition as defined previously. At the handover, the towing company must be informed about the following points:

- $\quad$ Electric (or hybrid) powertrain;

- Firefighting measures that took place;

- State of the high voltage system;

- Potential danger from damaged high voltage components;

- Battery in contact with water;

- Risk of electric shock;

- Possibility of a delayed re-ignition of the traction battery [20].

Generally, for road transportation of dangerous goods, the regulations of the ADR (Accord européen relatif au transport international des marchandises dangereuses par route) [78] need to be fulfilled. However, this does not apply to the removal of a wrecked vehicle from the accident location, because this clearing procedure is defined as an emergency procedure and thus exempted from the regulations [78].

Depending on severity of the accident, different approaches for the follow-up procedures can be selected. Figure 4 displays the different destinations for a wrecked vehicle to be stored safely by the towing company.

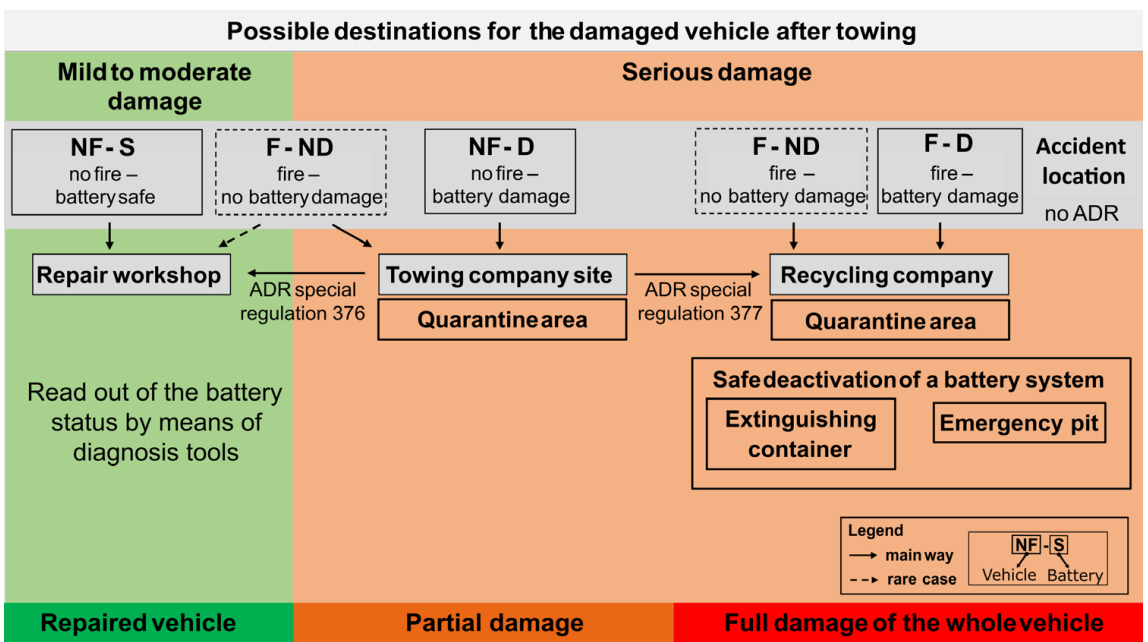

Figure 4. Possibilities for a towing company to unload an accident-damaged electric vehicle.

On the left column, vehicles that show only moderate damage and especially no detectable damage to the battery (NF-S) are transported (ADR SV 376) to a repair workshop. With a dedicated interface tool, contract workshops are able to gain more information about the battery state. With no severe failures on the traction system, the vehicle can be repaired normally. In case of a small local fire that has not affected the battery (F-ND) the same scheme can be applied. If the fire was big enough to result in an otherwise total loss (without damaging parts of the battery) or there was no fire at all, but the battery was in a critical state (NF-D), it is useful to setup a quarantine area at the company site, where the vehicle can be stored and monitored. A place qualifies as a quarantine area, if there are no flammable objects, other vehicles, or buildings close-by, as electrical vehicles may re-ignite time-shifted and the fire could spread [79]. For forensic tasks and securing of evidence, the vehicle should be protected from weather influences. A locked tent would be suitable, as its fire load is less than that of an actual building [60]. Another possibility is a fire protection cover, like a so-called Rescue Bag [80]. For transportation, a damaged electric vehicle can be completely wrapped in this special cover by the towing company or for storage at the quarantine area. The Rescue Bag consists of self-extinguishing fabric. When a vehicle fire occurs, the generated heat releases gases in the fabric, which suppress the fire. The fabric is permeable for gases and prevents heat accumulation beneath the cover [80]. 
The required size for a quarantine area is not yet regulated and varies depending on different car manufacturer specifications [79]. Tesla and Hyundai for example recommend a spacing of at least $15 \mathrm{~m}$ between the vehicle and any surroundings $[67,73]$. Whereas Audi suggests a distance of at least $5 \mathrm{~m}$ between the vehicle and surrounding buildings [68]. Original equipment manufacturers (OEM) require their authorized dealerships and service partners to provide such a designated area [79]. If possible, the available battery data will be read out by a certified electrician [8] by means of a diagnosis tools in order to further assess the state of the battery. When all procedures on the quarantine area are finished, including the waiting periods, the vehicle can be transported to a recycling company, where it will be fully deactivated, dismantled, or repurposed. The same path applies for burned out vehicles that ended in a total loss after fire (F-D).

Emergency containers for wrecked electric vehicles are a second option for keeping the vehicle in a safe environment. Those can be used for either flooding the vehicle, which would result in a total loss or they can be used for transporting the vehicle without water, and only be flooded in a critical condition in order to contain flame bursts, flying particles, or electrolyte spillage. Major negative aspects are the high purchase costs, the removal of the contaminated water and the logistical effort, especially for towing or for the recycling company. This deactivation method is currently not standardized. In addition, the disposal of the contaminated water is not yet regulated [81]. Analogue to containers, emergency pits can be established at dedicated locations, e.g., at designated areas of recycling companies that serve the same purpose as a container, but are stationary. When flooded with water, the chemical energy of the storage is released over time, due to corrosion of the metals and self-discharge [82]. However, these processes can take several days and are not suited for road traffic fires [69]. The subsequent steps for the recycling process are explained in the next section.

\subsection{Recycling}

The transportation of the damaged vehicle (including high voltage battery) from the towing company site to the recycling company is not classified as an emergency and therefore subject to special regulation 377 of the ADR [78,83]. In Table 1, an outline of the processes, companies, qualification, and more is given. In the beginning, the traction battery needs to be discharged, separated from the vehicle body and disassembled. This task requires high voltage qualification [8,84] and special equipment-such as completely insulated, voltage proof tools-to protect the operators from electric shock and to lower the risk of short circuiting the system [84].

Table 1. Overview of the recycling procedures in Germany, with separation of the battery from the vehicle, disassembly of the battery and material feedback with inclusion of regulations, necessary qualifications, and recovered materials.

\begin{tabular}{|c|c|c|c|c|c|}
\hline Tasks & Work Field & Regulation & Qualification & Processes & Recovered Materials \\
\hline $\begin{array}{l}\text { Removal of the } \\
\text { battery from the } \\
\text { vehicle }\end{array}$ & $\begin{array}{l}\text { Recycling } \\
\text { companies }\end{array}$ & $\begin{array}{l}\text { DGUV } 8686 \\
{[8]}\end{array}$ & $\begin{array}{c}\text { Level } 2 \\
\text { Non-electrical work } \\
{[8]}\end{array}$ & $\begin{array}{l}\text { Deactivation, check for no } \\
\text { voltage, removal }\end{array}$ & - \\
\hline $\begin{array}{l}\text { Disassembly of the } \\
\text { residual vehicle }\end{array}$ & $\begin{array}{c}\text { Certified } \\
\text { dismantling } \\
\text { facilities } \\
\text { [89] }\end{array}$ & $\begin{array}{l}\text { EU End-of-Life Vehicles } \\
\text { Directive (Directive } \\
2000 / 53 / \text { EC) [90] and } \\
\text { EU Waste Directive } \\
\text { (Directive 2008/ } \\
\text { 98/EC) } \\
\text { [91] }\end{array}$ & $\begin{array}{l}\text { Respective } \\
\text { training }\end{array}$ & $\begin{array}{c}\text { Two-step-process: } \\
\text { liquid removal + } \\
\text { dismantling of } \\
\text { components containing } \\
\text { pollutants and shredding } \\
\text { of the body } \\
\text { [89] }\end{array}$ & $\begin{array}{c}\text { Steel, copper, light and } \\
\text { precious metals, glass, } \\
\text { tires and plastics, oils, } \\
\text { brake fluids } \\
\text { [89] }\end{array}$ \\
\hline $\begin{array}{l}\text { Disassembly of the } \\
\text { battery systems to cell } \\
\text { or module level }\end{array}$ & $\begin{array}{l}\text { Recycling } \\
\text { companies }\end{array}$ & $\begin{array}{c}\text { DGUV } 8686 \\
{[8]}\end{array}$ & $\begin{array}{c}\text { Level } 3 \\
\text { Working under high } \\
\text { voltage } \\
\text { circumstances } \\
{[8]}\end{array}$ & $\begin{array}{l}\text { Module disassembly; } \\
\text { partly } \\
\text { robotic aided battery } \\
\text { disassembly } \\
{[85,86]}\end{array}$ & $\begin{array}{c}\text { Copper bus bars, } \\
\text { cabling, printed circuit } \\
\text { boards (PCB), plastics } \\
{[32,83]}\end{array}$ \\
\hline \multirow[b]{2}{*}{$\begin{array}{l}\text { Feeding the cell parts to } \\
\text { process }\end{array}$} & \multirow[b]{2}{*}{$\begin{array}{l}\text { Battery } \\
\text { recycling }\end{array}$} & \multirow{2}{*}{$\begin{array}{c}\text { EU directive } \\
\text { 2006/66/EC on battery } \\
\text { waste } \\
{[88]}\end{array}$} & \multirow[b]{2}{*}{$\begin{array}{l}\text { Respective } \\
\text { training }\end{array}$} & Pyro metallurgical & $\begin{array}{c}\text { Nickel, cobalt, copper } \\
{[32,83]}\end{array}$ \\
\hline & & & & $\begin{array}{c}\text { Pyro metallurgical and } \\
\text { Hydrometallurgical } \\
\text { [87] }\end{array}$ & $\begin{array}{c}\text { Nickel, cobalt, lithium } \\
{[87]}\end{array}$ \\
\hline
\end{tabular}


Because of the different designs of the traction systems, its complete disassembly requires qualified specialists. From different voltage levels, cooling concepts, module design, wiring harnesses, cell designs and chemistries, every car manufacturer uses his own design and techniques [84]. Even designs from a single manufacturer vary from model to model [85]. Therefore, robots are used in pilot projects, to avoid these risks and reduce costs $[85,86]$. Only by separating the cells and modules from the remaining components like packaging material, housings, circuit boards or cables they can be fed into their respective recycling processes [32,83].

At this step, once the modules and potentially cells are stripped from the system, they can easily be reused in different projects and get a second life. Beforehand, their electrical capabilities need to be evaluated and the appropriate use case has to be selected. If a second life is not useful economically, the cells and modules will be recycled.

Recycling at the cell level has aims to recover a high rate of nickel, cobalt, and copperfor example, by pyro metallurgical processes, by means of heating up the battery cells in a furnace to very high temperatures. The contained metals melt and are separated $[32,83,87]$.

By treating parted active materials with alkaline solutions, metals can be dissolved in a so-called hydrometallurgical process [87]. To regain lithium, pyro metallurgical combined with hydrometallurgical processes are being used [87].

The LithoRec-process is another way to regain large parts of lithium, cobalt and nickel by utilizing mechanical and hydrometallurgical methods in the process $[32,87]$.

From an economic and ecological point of view, the recovery of metals and the followed feed back into the industrial circulation are important aspects that are mandatory to fulfill the battery recycling quota of more than $50 \%$ that is requested by the EU directive on battery waste $[83,88]$.

\section{Discussion of Current State and Recommendations}

\subsection{Information Transfer About the Powertrain}

In order to recommend any changes for the general procedure of managing crashed electric vehicles, there are still a few challenges that need to be addressed and discussed.

The dispatcher of the PSAP receives information about the powertrain by the eCall. It is recommended that this significant information must always be transferred to the rescue services. Besides the standard radio messages, a new standard procedure shall be implemented in the future. This could be achieved by digital transmission of the data onto a terminal device at the rescue team. This allows future updates and implementation of additional data, such as internal cell temperatures or battery state parameters to the team.

Information about battery and powertrain shall either be passed on from the firefighters to the police, which again forwards it to the towing company [62] or provides it to all three parties. If this information is forwarded orally, the towing service can send an employee, who is level 2 qualified according to DGUV Information 8686 [8], to the accident location. In addition, it is also recommended for every towing company, to have at least a single driver that is capable of safely transporting damaged electric vehicles, in the best case every driver is qualified for this task.

\subsubsection{Assessment of the Battery State}

One of the main obstacles for the arriving rescue team is the external estimation of the status of the high voltage battery. Especially in scenarios, where the battery housing shows visible intrusion but no smoke or flames, no precise assertion about the level of damage can be made.

The observation period in case of an unidentified and maybe even critical battery, can last one hour according to Tesla's emergency manual. When there is no flame, smoke, or heat development, the vehicle can be transferred to second responders [67]. It is proposed that this observation period shall be doubled in critical and undefined cases to ensure safety, especially for the towing service. 
The uncertainty of the actual battery state similarly occurs when the vehicle is already on fire and it is hard to determine whether the battery is involved or not. Without actual insight of the battery data, there is always the risk of misjudging the situation, resulting in serious consequences for all participating parties. Every traction battery has a BMS that monitors all relevant battery parameters, such as various temperatures, single cell voltages, system voltage, interlock state and contactor positions. Therefore, this information is already present in the battery system. However, to the misfortune of the rescue services, this data is not accessible. Only the vehicle manufacturer can access this data. Unfortunately, the data sets are encrypted and only available by using a suitable interface, as detailed information about the battery is not shared over the on-board diagnosis (OBD) port, although depending on the manufacturer. This can be resolved by establishing a universal interface for reading out battery data of every electric vehicle on market, but that is not the case right now. An extension of the OBD standard with BMS data would not necessarily solve this problem for the firefighters, because they would need to be close to the interior of the vehicle, or even inside it, while the battery is still in a critical state and could spontaneously ignite.

A concept similar to the OBD extension would be a so-called Event Data Recorder (EDR), which acts like a black box. When the device is triggered by a crash signal from the vehicle, the EDR's circular buffer storage saves the vehicle's data $5 \mathrm{~s}$ prior to and usually $250 \mathrm{~ms}$ after the crash [92].

The accident data set is selected to be useful for forensic evaluation and is usually accessed by a cable link connected to the vehicle. Accordingly, this method is not suitable for the rescue team during the emergency, as they need to be close to the vehicle. Although it can be useful for the crash reconstruction and the determination of the fire source afterwards.

The AHEAD (Aggregated Homologation proposal for Event data recorder for Automated Driving) Data Model of Technische Hochschule Ingolstadt, Germany, suggests a future EDR with a minimalized set of data that is required for the clarification of the accident. The data set is sent automatically to a data trust center over the air and can be used for accident reconstructions [93]. Ideally, this interface would also be at hand directly after a crash of an EV.

In a similar manner, to gain access to relevant BMS data without a directly connected interface, and thus for not putting the firefighters in danger, a dedicated setup by wireless transmission can be realized. Currently there are no available possibilities on the market, but there are concepts for sending relevant battery data via mobile network (e.g., LTE) to a server that is accessible by the PSAP [94]. This information can ease the further handling and extinguishing measures for the firefighters in the field. Even if there are already ideas and patents discussing this topic, the actual implementation-especially with a unified agreed solution-still has many challenges ahead.

A recommended solution is to implement the mentioned aspects into requirements for newly designed EVs. The European council needs to agree upon a solution and force regulations into existence by law. Until this time, the previously discussed points about controlling the fire (see Section 3.2.2) help to give a precise estimation of the vehicle status. On the long run, especially with a much higher quota of electrically propelled vehicles on the roads, a new harmonized solution needs to be implemented.

\subsubsection{Extinguishing Methods}

When the state of the battery can be estimated with high confidence, the correct and precise countermeasures by the firefighters can be applied in a safe manner. Besides extinguishing with a conventional direct water jet, two different approaches are commonly discussed: the extinguishing lance and mobile extinguishing containers.

There are chances and risks of utilizing an extinguishing lance. On the one hand, the lance has the great advantage of getting cool water with high thermal capacity directly to the source of fire and thus inhibit further thermal propagation to still functional and 
safe areas of the battery. The direct cooling delivers a much better performance than just cooling from the outside. The water is able to penetrate all small niches between the cell modules and housing and, depending on the ingress protection of the modules, even the spaces between the cells. On the other hand, the existing risk of puncturing the wrong area of the battery with the lance, causing a short circuit and even initiating a thermal runaway, needs to be minimized. A wrecked EV battery might still be in a stable state, even if the battery system is mechanically damaged. This can lead to the wrong assessment of further extinguishing the battery with a lance, resulting in a bigger hazard than before. This apprehension is reinforced by the fact that designated puncture markings are not available in each rescue data sheet $[67,68,71-73]$, leaving firefighters to take their chance and proceed with their own assessment. If the extinguishing lance will be widely used by rescue services in the future, OEMs need to provide clear markings in the data sheet, possibly marks on the battery casing itself and incorporate this aspect during development of the system.

The second discussed option for extinguishing and deactivating EVs are extinguishing containers. Currently, various companies are developing mobile extinguishing containers that are designed for recovery of wrecked electric vehicles [95-97]. The precooled vehicle can be towed onto the payload area of the container. After the closing and sealing of the gate, the vehicle in theory can be flooded. Flooding with water prevents further selfignition and leads to a complete deactivation of the battery system over time [95]. When the vehicle is fully flooded, it still needs to be monitored, as delayed reactions of water entering the battery can produce short circuits and heat. The authors recommend, based on experimental experience, to continue monitoring the flooded system for at least two days.

On the other hand, flooding an EV should be viewed as a special case and not as the standard procedure, as less hazardous accidents would result in total damage, where flooding would not have been necessary. The risk of flooding every wrecked vehicle is a potential disadvantage of the container and could also impair the image of EVs, further influence purchasing decisions for new customers and even raise the insurance premiums for EVs.

In addition, the disposal of the contaminated water is an expensive undertaking, especially for recycling companies. The high purchase costs of such containers as well as the logistical handling are still obstacles to be overcome. If the container is loaded with water including a vehicle, it can weigh up to 14 tons [96], resulting in a heavy-duty transport with dangerous goods. An unflooded transport is lighter and incorporates less effort for transportation in general, leading to the possible solution of flooding the vehicle only at the destination, e.g., the quarantine area introduced above. The overall necessity of the container for hazardous electric vehicles at accident location is not a discussion that can be solved finally, as it depends on many circumstances. Although, the incorporation of isolating containers on a quarantine area may be a space saving solution for recycling and towing companies, as they can be placed much closer together than just the vehicles on a plain. On a lookout, future containers might be equipped with special mechanisms-such as spray extinguishers, gas monitoring, intelligent monitoring of the vehicle state, and automatic warning and extinguishing measures.

For a safer transportation away from the accident site, the extinguished vehicle can be wrapped with a fireproof protection cover. In the end, it will be demonstrated which technology will succeed under real conditions during emergency situations.

\subsubsection{Quarantine Area}

Another open topic is the provisioning of the quarantine area. As OEMs sub-distribute this task to their service partners and vehicle dealers [79], the disadvantage of reachability plays a new role, due to limited business hours of these companies. A useful alternative would be to dispone this task to another party; recommended solutions would be the towing companies or the recycling companies. The fire department could also come to mind, but to assign them the task of managing and monitoring wrecked vehicles would be outside 
of their area of responsibility. Depending on the severity of the crash and the occurrence of fire, it is recommended that the wrecked EV can be transported to the quarantine area as a first halt. The towing company can provide this area, where observation, forensic analysis, and diagnoses of the vehicle can be carried out. For completely burned out vehicles, it is suggested that the recycling company should provide space for the deportation of wrecks in the future. In special cases, containers or water pits at that area can help to deactivate the battery by flooding.

\section{Summary}

At present, the correct estimation of the high voltage battery status at the accident location represents the biggest challenge for the rescue team. In order to further push electric mobility and lower the risks for all concerned parties, the uncertainties regarding the actual battery state need to be eliminated. Interestingly, the present problems are theoretically solvable with current state of technology. The authors recommend a wireless transmission of live battery data to the rescue team on site. Possible low- to mid-range standards such as Bluetooth, can be used to transmit the data. The vehicle is equipped with a small transceiver that is hooked to an independent power supply. Rescue services are in possession of a terminal device, e.g., a smartphone that is linked with the vehicle and displays key parameters of the battery. It is necessary after all, to secure this access point with enough protection in order to maintain privacy of the vehicle owner. However, the main problem is that there are no common regulations yet on how this information can be transferred to the rescue team on location with a common interface or another suitable solution. For this purpose, the European Council must create uniform regulations by law.

Direct internal cooling of the battery by extinguishing lance or complete deactivation of the whole vehicle inside an emergency container represent good possibilities and a shift to a safe state, but needs to be tackled in future investigations and validated with real world data. Wrecked electric vehicles must be placed outside at a designated place, with no fire load in the surrounding area. The towing company or, in case of a completely burned out vehicle, the recycling company has to provide this area.

None of these current obstacles represent an overwhelmingly difficult barrier for a fully electric future, but some challenges simply need to be addressed by legislators, in order for the automotive companies to come up with suitable solutions to those challenges. Of course, car manufacturers could already develop non-legislated standards to cope with the problem for the rescue services, but without pressure from given law, this scenario is unlikely.

In the end, electric mobility should not only be a green alternative to current technology, but also as safe and accessible as its competing technologies.

Author Contributions: Conceptualization, K.W. and C.G.; methodology, K.W., C.G., C.N., and S.L.; formal analysis, K.W., C.G., C.N., S.L., and H.-G.S.; investigation, K.W.; writing-original draft preparation, K.W. and C.G.; writing-review and editing, K.W., C.G., C.N., and H.-G.S.; visualization, K.W.; supervision, H.-G.S.; project administration, H.-G.S. All authors have read and agreed to the published version of the manuscript.

Funding: This research was funded by EFRE-supported EU research network project SENSE BAY, grant number EU-1802-0005 as well as the HORIZON2020-supported EU project COBRA, grant number H2020-EU.3.4, 875568.

Acknowledgments: This work was supported by the Technische Hochschule Ingolstadt.

Conflicts of Interest: The authors declare no conflict of interest.

\section{References}

1. Lotfi, N.; Fajri, P.; Novosad, S.; Savage, J.; Landers, R.G.; Ferdowsi, M. Development of an Experimental Testbed for Research in Lithium-Ion Battery Management Systems. Energies 2013, 6, 5231-5258. [CrossRef]

2. Kim, G.H.; Smith, K.; Ireland, J.; Pesaran, A. Fail-safe design for large capacity lithium-ion battery systems. J. Power Sour. 2012, 210, 243-253. [CrossRef] 
3. Regulation (EU) 2019/631 of the European Parliament and of the Council of 17 April 2019 Setting CO2 Emission Performance Standards for New Passenger Cars and for New Light Commercial Vehicles, and Repealing Regulations (EC) No 443/2009 and (EU) No 510/2011. 2019. Available online: http://data.europa.eu/eli/reg/2019/631/oj (accessed on 3 August 2020).

4. IEA. Verteilung der Energiebedingten $\mathrm{CO}_{2}$-Emissionen Weltweit nach Sektor im Jahr 2018. Available online: https://de. statista.com/statistik/daten/studie/167957/umfrage/verteilung-der-co-emissionen-weltweit-nach-bereich/ (accessed on 3 August 2020).

5. Europäische Kommission. Saubere Mobilität: Parlament und EU-Staaten Einig über Neue CO2-Grenzwerte für Autos. Available online: https:/ / ec.europa.eu/germany/news/20181218-co2-grenzwerte-autos_de (accessed on 3 August 2020).

6. KBA. Anzahl der Neuzulassungen von Elektroautos in Deutschland von 2003 bis Oktober 2020. Available online: https:// de. statista.com/statistik/daten/studie/244000/umfrage/neuzulassungen-von-elektroautos-in-deutschland/statisticContainer (accessed on 19 November 2020).

7. UNECE. Agreement Concerning the Adoption of Uniform Conditions of Approval and Reciprocal Recognition of Approval for Motor Vehicle Equipment and Parts: Addendum 11: Regulation No. 12; UN: Geneva, Switzerland, 2012.

8. Deutsche Gesetzliche Unfallversicherung e.V., (DGUV). DGUV Information 8686 Qualifizierung für Arbeiten an Fahrzeugen mit Hochvoltsystemen. April 2012. Available online: https://publikationen.dguv.de/widgets/pdf/download/article/889 (accessed on 15 February 2021).

9. UNECE. Agreement Concerning the Adoption of Uniform Technical Prescriptions for Wheeled Vehicles, Equipment and Parts which can be Fitted and/or be Used on Wheeled Vehicles and the Conditions for Reciprocal Recognition of Approvals Granted on the Basis of these Prescriptions: Addendum 99: Regulation No. 100, 2nd ed.; UNECE: Geneva, Switzerland, 2013.

10. Porsche, A.G. Taycan 4S. Available online: https://www.porsche.com/germany/models/taycan/taycan-models/taycan-4s/ (accessed on 15 January 2021).

11. Nedelea, A. Hyundai Ioniq 5 Electric Crossover Teased Ahead of Imminent Reveal. Available online: https: / insideevs.com/ news /465953/hyundai-ioniq-5-ev-teased-before-launch/ (accessed on 15 January 2021).

12. Wang, Z.; Shi, S.; Liu, P. Research Progress on Collision Safety of Electric Vehicles. In Proceedings of the 2011 Third International Conference on Measuring Technology and Mechatronics Automation, Shanghai, China, 6-7 January 2011; pp. 153-156. [CrossRef]

13. Spotnitz, R.; Franklin, J. Abuse behavior of high-power, lithium-ion cells. J. Power Sour. 2003, 113, 81-100. [CrossRef]

14. Spotnitz, R.M.; Weaver, J.; Yeduvaka, G.; Doughty, D.H.; Roth, E.P. Simulation of abuse tolerance of lithium-ion battery packs. J. Power Sour. 2007, 163, 1080-1086. [CrossRef]

15. Petereit, D. Österreichischer Unfall-Tesla: Batterie hat Nicht Gebrannt. Available online: https://t3n.de/news/oesterreichischerunfall-tesla-1225910/ (accessed on 8 December 2020).

16. Global Technical Regulation on the Electric Vehicle Safety (EVS): Addendum 20: Global Technical Regulation No. 20.2018. Available online: https:/ / unece.org/transport/standards/transport/vehicle-regulations-wp29/global-technical-regulations-gtrs (accessed on 19 August 2020).

17. UNECE. Agreement Concerning the Adoption of Uniform Technical Prescriptions for Wheeled Vehicles, Equipment and Parts which can be Fitted and/or be Used on Wheeled Vehicles and the Conditions for Reciprocal Recognition of Approvals Granted on the Basis of These Prescriptions: Addendum 93: Regulation No. 94, 3rd ed.; UN: Geneva, Switzerland, 2017.

18. UNECE. Agreement Concerning the Adoption of Uniform Technical Prescriptions for Wheeled Vehicles, Equipment and Parts which can be Fitted and/or be Used on Wheeled Vehicles and the Conditions for Reciprocal Recognition of Approvals Granted on the Basis of These Prescriptions: Addendum 94: Regulation No. 95, 2nd ed.; UN: Geneva, Switzerland, 2014.

19. UNECE. Agreement Concerning the Adoption of Uniform Technical Prescriptions for Wheeled Vehicles, Equipment and Parts which can be Fitted and/or be Used on Wheeled Vehicles and the Conditions for Reciprocal Recognition of Approvals Granted on the Basis of These Prescriptions: Addendum 134: Regulation No. 135, 1st ed.; UN: Geneva, Switzerland, 2016.

20. VDA Verband der Automobilindustrie-Project group. Recovery of vehicles with high-voltage systems from accidents. Accident Assistance and Recovery of Vehicles with High-Voltage Systems: Frequently Asked Questions (FAQs). Available online: https: / www.vda.de/dam/vda/publications / Rescue \%20\&\%20Towing\%20of\%20Vehicles\%20with\%20High-Voltage\%20 Systems / Accident_Assistance_Recovery_FAQ_en_20170721.pdf (accessed on 15 February 2021).

21. Wang, Q.; Ping, P.; Zhao, X.; Chu, G.; Sun, J.; Chen, C. Thermal runaway caused fire and explosion of lithium ion battery. J. Power Sour. 2012, 208, 210-224. [CrossRef]

22. Larsson, F.; Bertilsson, S.; Furlani, M.; Albinsson, I.; Mellander, B.E. Gas explosions and thermal runaways during external heating abuse of commercial lithium-ion graphite-LiCoO2 cells at different levels of ageing. J. Power Sour. 2018, 373, 220-231. [CrossRef]

23. Zhang, J.; Su, L.; Li, Z.; Sun, Y.; Wu, N. The Evolution of Lithium-Ion Cell Thermal Safety with Aging Examined in a Battery Testing Calorimeter. Batteries 2016, 2, 12. [CrossRef]

24. Geisbauer, C.; Wöhrl, K.; Mittmann, C.; Schweiger, H.G. Review of Safety Aspects of Calendar Aged Lithium Ion Batteries. J. Electrochem. Soc. 2020, 167, 90523. [CrossRef]

25. Thermal and Electrical failure analysis of lithium-ion battery after crash. In Proceedings of the International Electrical Engineering Conference IEEC 2017, Karachi, Pakistan, 19-20 May 2017.

26. Sahraei, E.; Campbell, J.; Wierzbicki, T. Modeling and short circuit detection of $18650 \mathrm{Li}$-ion cells under mechanical abuse conditions. J. Power Sour. 2012, 220, 360-372. [CrossRef] 
27. Isidore, C. Volt fire 3 Weeks After Crash Prompts Safety Probe. Available online: https://money.cnn.com/2011/11/11/autos/ volt_crash_fire/index.htm (accessed on 20 November 2020).

28. Wojdyla, B. The Straight Story on the Chevy Volt Battery Fire. Available online: https://www.popularmechanics.com/cars/ hybrid-electric/a11865/the-straight-story-on-the-chevy-volt-battery-fire-6601217/ (accessed on 20 November 2020).

29. Luo, W.T.; Zhu, S.B.; Gong, J.H.; Zhou, Z. Research and Development of Fire Extinguishing Technology for Power Lithium Batteries. Procedia Eng. 2018, 211, 531-537. [CrossRef]

30. Blum, A.; Long, R.T. Full-scale Fire Tests of Electric Drive Vehicle Batteries. SAE Int. J. Passeng. Cars Mech. Syst. 2015, 8, 565-572. [CrossRef]

31. Deutsche Gesetzliche Unfallversicherung e.V., (DGUV). DGUV Information 205-022 Rettungs- und Löscharbeiten an PKW mit alternativer Antriebstechnik. December 2012. Available online: https://publikationen.dguv.de/widgets/pdf/download/article/ 2595 (accessed on 15 February 2021).

32. Kwade, A.; Diekmann, J. Recycling of Lithium-Ion. Batteries; Springer International Publishing: Cham, Switzerland, 2018.

33. Gores, H.J. Liquid Nonaqueous Electrolytes. In Handbook of Battery Materials; Daniel, C., Besenhard, J.O., Eds.; Wiley-VCH Verlag GmbH \& Co. KGaA: Weinheim, Germany, 2011; pp. 525-626.

34. Klose, R. Fluorine Recycling for Lithium-ion Batteries. Available online: https:/ /www.empa.ch/web/s604/fluoribat (accessed on 20 November 2020).

35. Larsson, F.; Andersson, P.; Blomqvist, P.; Mellander, B.E. Toxic fluoride gas emissions from lithium-ion battery fires. Sci. Rep 2017, 7, 10018. [CrossRef]

36. Zhao, D.; Lei, D.; Wang, P.; Li, S.; Zhang, H.; Cui, X. Synthesis, Water-Removing Method and Influences of Trace Water for LiBF 4. ChemistrySelect 2019, 4, 5853-5859. [CrossRef]

37. Bajraktarova-Valjakova, E. Hydrofluoric Acid: Burns and Systemic Toxicity, Protective Measures, Immediate and Hospital Medical Treatment. Open Access Maced. J. Med Sci. 2018, 6, 2257-2269. [CrossRef] [PubMed]

38. Flusssäure, M. 40\%—Data sheet. Available online: https://www.merckmillipore.com/DE/de/product/Hydrofluoric-acid-400-0, MDA_CHEM-100338 (accessed on 4 August 2020).

39. Kirkpatrick, J.J.R.; Enion, D.S.; Burd, D.A.R. Hydrofluoric acid burns: A review. Burns 1995. [CrossRef]

40. Qiao, Y.; Wang, S.; Gao, F.; Li, X.; Fan, M.; Yang, R. Toxicity analysis of second use lithium-ion battery separator and electrolyte. Polym. Test. 2020, 81, 106175. [CrossRef]

41. Hatai, J.K.; Weber, J.N.; Doizaki, K. Hydrofluoric Acid Burns of the Eye: Report of Possible Delayed Toxicity. J. Toxicol. Cutan. Ocul. Toxicol. 1986, 5, 179-184. [CrossRef]

42. Mayer, L.; Guelich, J. Hydrogen fluoride (HF) inhalation and burns. Arch. Environ. Health 1963, 7, 445-447. [CrossRef]

43. Wisch, M.; Ott, J.; Thomson, R.; Léost, Y.; Abert, M.; Yao, J. Recommendations and Guidelines for Battery Crash Safety and Post-Crash Safe Handling. EVERSAFE—Everyday Safety for Electric Vehicles. 2014. Available online: https:/ / www.diva-portal. $\mathrm{org} / \mathrm{smash} /$ record.jsf?pid=diva2\%3A1367933\&dswid=-7667 (accessed on 20 November 2020).

44. Deutsche Gesetzliche Unfallversicherung e.V. (DGUV). FAQ-Liste der AG “Handlungsrahmen Elektromobilität”. August 2016. Available online: https://www.dguv-vorsorge.de/medien/fb-holzundmetall/sachgebiete/fahrzeug/elektromobilitaet/faq_ elekro.pdf (accessed on 15 February 2021).

45. UNC. International Integrity and Risk Management. Chemical Safety Information-Hydrofluoric Acid. Available online: https: / / ehs.unc.edu/chemical/hfa/chemical-safety-information-hydrofluoric-acid/ (accessed on 4 August 2020).

46. Lecocq, A.; Bertana, M.; Truchot, B.; Marlair, G. Comparison of the Fire Consequences of an Electric Vehicle and an Internal Combustion Engine Vehicle. In Proceedings of the 2nd International Conferenceon Fires In Vehicles-FIVE 2012, Chicago, IL, USA., 27-28 September 2012.

47. HELLA KGaA Hueck \& Co. Füllmenge Klimaanlage: Kältemittel und Ölfüllmengen. Available online: https:/ / www.hella.com/ techworld/de/Technik/Klimatisierung/Fuellmenge-Klimaanlage-2114/ (accessed on 20 November 2020).

48. Bundesrepublik Deutschland. Strafgesetzbuch (StGB) § 323c Unterlassene Hilfeleistung; Behinderung von hilfeleistenden Personen. Available online: https://www.gesetze-im-internet.de/stgb/_323c.html (accessed on 15 February 2021).

49. Regulation (EU) 2015/758 of the European Parliament and of the council concerning type-approval requirements for the deployment of the eCall in-vehicle system based on the 112 service and amending Directive 2007/46/EC. 2015. Available online: https: / / eur-lex.europa.eu/legal-content/EN/TXT/?uri=celex:32015R0758 (accessed on 20 November 2020).

50. Beuth Verlag GmbH. DIN EN 15722 Intelligent transport systems—ESafety_ECall Minimum Set of Data; DIN-Normenausschuss Automobiltechnik (NA Automobil), 2015.

51. Beuth Verlag GmbH. DIN EN 16102 Intelligent Transport Systems—eCall—Operating Requirements for Third Party Support; Normenausschuss Automobiltechnik (NA Automobil) im DIN, 2012.

52. Beuth Verlag GmbH. DIN EN 16062 Intelligent Transport Systems—ESafety—eCall High Level Application Requirements (HLAP) Using GSM/UMTS Circuit Switched Networks. DIN-Normenausschuss Automobiltechnik (NAAutomobil), 2015.

53. Bundesanstalt für den Digitalfunk der Behörden und Organisationen mit Sicherheitsaufgaben, Endgeräte. Available online: https:/ / www.bdbos.bund.de/DE/Fachthemen/Endgeraete/endgeraete_node.html (accessed on 20 November 2020).

54. Gesetz über die Errichtung einer Bundesanstalt für den Digitalfunk der Behörden und Organisationen mit Sicherheitsaufgaben (BDBOS-Gesetz-BDBOSG). 2006. Available online: https://www.umwelt-online.de/recht/anlasi/bdbosg_ges.htm (accessed on 20 November 2020). 
55. Bundesrepublik Deutschland. Grundgesetz für die Bundesrepublik Deutschland Art 70. Available online: https://www.gesetze-iminternet.de/gg/art_70.html (accessed on 15 February 2021).

56. Schehadat, M.S.; Groneberg, D.A.; Bauer, J.; Bendels, M.H.K. Hilfsfristen des Rettungsdienstes in den deutschen Bundesländern. Zbl Arbeitsmed (Zentralblatt für Arbeitsmedizin, Arbeitsschutz und Ergonomie. 2017, 67, 255-260. [CrossRef]

57. Staatliche Feuerwehrschule Würzburg. Alternativ Angetriebene Fahrzeuge. 2017. Available online: https://www.ffw-seukendorf. de/wp-content/uploads/2020/01/Merkblatt.pdf (accessed on 14 September 2020).

58. Deutsche Automobil Treuhand GmbH, SilverDAT ${ }^{\circledR}$ —Immer up to DATe!: Das fabrikatsübergreifende Daten und Informationssystem. Available online: https:/ / www.dat.de/silverdat/ (accessed on 20 November 2020).

59. Moditech Rescue Solutions, Was ist das Crash Recovery System? Available online: https://www.moditech.com/de/crashrecovery-system/ (accessed on 20 November 2020).

60. Harendt, B.; Dietrich, N.; Doser, J.W.; Mayer, C.; Erling, U. Elektromobilitätsgesetz (EmoG) Gesetz zur Bevorrechtigung der Verwendung elektrisch betriebener Fahrzeuge, Frankfurt am Main. June 2018. Available online: https://www.bmu.de/fileadmin/ Daten_BMU/Download_PDF/Verkehr/emog_bericht_2018_bf.pdf (accessed on 20 November 2020).

61. Statistisches Bundesamt (Destatis), Verkehr: Verkehrsunfälle. Available online: https://www.destatis.de/DE/Themen/ Gesellschaft-Umwelt/Verkehrsunfaelle/Publikationen/Downloads-Verkehrsunfaelle/verkehrsunfaelle-jahr-2080700197004. pdf?_blob=publicationFile (accessed on 20 November 2020).

62. Wöhrl, K.; Nebl, C.; Lott, S.; Geisbauer, C.; Le Roux, F.; Schweiger, H.-G. Handling of accident-damaged electric vehicles. In Automotive Technologie in Bavaria e-Car + Hydrogen; Media mind GmbH \& Co. KG: Munich, Germany, 2020; pp. 16-21. Available online: https://media-mind.info/pdf/2020/automobil_eng_2020.pdf (accessed on 25 November 2020).

63. Doughty, D.; Crafts, C. FreedomCAR Electrical Energy Storage System Abuse Test Manual for Electric and Hybrid Electric Vehicle Applications: Sandia Report SAND2005-3123; Sandia National Laboratories: Albuquerque, NM, USA; Livermore, CA, USA, 2006.

64. Deutsche Gesetzliche Unfallversicherung e.V. (DGUV). Hinweise für die Brandbekämpfung von Lithium-Ionen-Akkus bei Fahrzeugbränden. July 2020. Available online: https://publikationen.dguv.de/widgets/pdf/download/article/3907 (accessed on 24 November 2020).

65. Geib, C.; Nebl, C.; Huber, J.; Schweiger, H.-G. Herausforderung Elektrofahrzeuge: Hilfestellung für den Einsatz. Brandwacht, I/2020; pp. 18-20. Bayerisches Staatsministerium des Innern, für Bau und Verkehr. München. 2020. Available online: https: //www.brandwacht.bayern.de/mam/archiv/beitraege_pdf/bw_1_2020_s18_20_e-autos2.pdf (accessed on 24 November 2020).

66. Cabrera-Castillo, E.; Niedermeier, F.; Jossen, A. Calculation of the state of safety (SOS) for lithium ion batteries. J. Power Sour. 2016, 324, 509-520. [CrossRef]

67. Tesla Motors. MODEL 3: Emergency Response Guide. Available online: https://www.tesla.com/sites/default/files/downloads/ 2017_Model_3_Emergency_Response_Guide_en.pdf (accessed on 9 December 2020).

68. Audi, A.G. Rettungsdatenblatt Audi E-Tron. Available online: https://rettungskarten-service.de/wp-content/uploads/Audi-etron-Baujahr-ab-2019.pdf (accessed on 9 December 2020).

69. Thorns, J. Einsatz der Feuerwehr- und des Rettungsdienstes an Elektrofahrzeugen: Forschungsprojekt mit Crashtests und Schneidversuchen. Available online: http:/ / www.feuerwehr-eggenfelden.com/images//Beitraege/Download/Elektrofahrzeuge.pdf (accessed on 8 December 2020).

70. MURER Feuerschutz GmbH. E-Löschlanze Bedienungsanleitung. Available online: https://www.murer-feuerschutz.de/_pdf/ELoeschlanze_BA_DE_komplett.pdf?m=1587380908\& (accessed on 4 December 2020).

71. Rettungsdatenblatt BMW 101 Kombilimousine (i3); BMW AG: Munich, Germany, 2016.

72. Rescue Data Sheet NISSAN LEAF: Typ: ZE1, 2017-SJNFAAZE1U0xxxxxx; NISSAN: Yokohama, Japan, 2018.

73. Rescue Data Sheet Hyundai Kona Electric (Type: OS). Hyundai Motor Company: Seoul, Korea.

74. Kagermeier, E. Wie gefährlich sind Brände bei E-Autos wirklich? Available online: https://www.br.de/nachrichten/wissen/wiegefaehrlich-sind-braende-bei-e-autos-wirklich, RoPFuv7 (accessed on 7 September 2020).

75. Sandén, B. Systems Perspectives on Electromobility: Chapter 4: Are Electric Vehicles Safer Than Combustion Engine Vehicles? Chalmers University of Technology: Göteborg, Sweden, 2013.

76. NFPA's Alternative Fuel Vehicles Safety Training Program: Emergency Field Guide; National Fire Protection Association: Quincy, MA, USA, 2015.

77. Deutsche Gesetzliche Unfallversicherung e.V. (DGUV). DGUV Information 214-010 Sicherungsmaßnahmen bei Pannen/Unfallhilfe, Bergungs- und Abschlepparbeiten. March 2019. Available online: https://publikationen.dguv.de/widgets/pdf/ download/article/566 (accessed on 15 February 2021).

78. ADR 2019; UNECE: Geneva, Switzerland, 2019.

79. Winkler, D. Kühlen, bis der Arzt kommt. In Auto Service Praxis; Springer Fachmedien München GmbH: München, Germany; pp. 14-16. Available online: http://media1.autoservicepraxis.de/fm/5468/90007_2020_24_03_I_014-017_n16_Hintergrund_EMobilitaet_423206_print.pdf (accessed on 26 November 2020).

80. Tatsch, O. IBENA Entwickelt Brandschutzdecke für Elektroautos und eBikes. Available online: https://protect.ibena.de/de/ news/ibena-entwickelt-brandschutzdecke-f\%C3\%BCr-elektroautos.html (accessed on 26 November 2020).

81. Mellert, L. Risk minimisation of Electric Vehicle Fires in Underground Traffic Infrastructures. Available online: https:/ / plus.empa. ch/images/2020-08-17_Brandversuch-Elektroauto/AGT_2018_006_EMob_RiskMin_Undergr_Infrastr_Final_Report_V1.0.pdf (accessed on 25 November 2020). 
82. Shaw-Stewart, J. Aqueous solution discharge of cylindrical lithium-ion cells. Sustain. Mater. Technol. 2019, 22, e00110. [CrossRef]

83. Korthauer, R. Lithium-Ion Batteries: Basics and Applications; Springer: Berlin/Heidelberg, Germany, 2018.

84. Harper, G. Recycling lithium-ion batteries from electric vehicles. Nature 2019, 575, 75-86. [CrossRef]

85. Wegener, K.; Chen, W.H.; Dietrich, F.; Dröder, K.; Kara, S. Robot Assisted Disassembly for the Recycling of Electric Vehicle Batteries. Procedia Cirp 2015, 29, 716-721. [CrossRef]

86. Thomé-Kozmiensky, K.J.; Goldmann, D. Recycling und Rohstoffe: Entwicklung eines Innovativen Verfahrens zur Automatisierten Demontage und Aufbereitung von Lithium-Ionen-Batterien aus Fahrzeugen; TK-Verl.: Neuruppin, Germany, 2012; Available online: http:/ / vivis.de/fachbuecher/recycling-und-rohstoffe/242-rur-5 (accessed on 4 December 2020).

87. Hanisch, C.; Haselrieder, W.; Kwade, A. Recycling von Lithium-Ionen-Akkus: Projekt LithoRec. Available online: https: //www.elektroniknet.de/elektronik/power/recycling-von-lithium-ionen-akkus-106499.html (accessed on 8 September 2020).

88. Directive 2006/66/ec of the European Parliament and of the Council on Batteries and Accumulators and Waste Batteries and Accumulators and Repealing Directive 91/157/eec. 2006. Available online: https:/ / eur-lex.europa.eu/legal-content/EN/ALL/ ?uri=CELEX\%3A32006L0066 (accessed on 15 September 2020).

89. Umwelt Bundesamt, Altfahrzeuge. Available online: https://www.umweltbundesamt.de/themen/abfall-ressourcen/ produktverantwortung-in-der-abfallwirtschaft/altfahrzeuge\#altfahrzeuge-in-deutschland (accessed on 7 September 2020).

90. Directive 2000/53/ec of The European Parliament and of the Council on End-of Life Vehicles. 2000. Available online: https: / / eur-lex.europa.eu/legal-content/EN/ALL/? uri=CELEX\%3A32000L0053 (accessed on 15 September 2020).

91. Directive 2008/98/ec of The European Parliament and of the Council on Waste and Repealing Certain Directives. 2008. Available online: https:/ / eur-lex.europa.eu/legal-content/EN/TXT/?uri=celex\%3A32008L0098 (accessed on 15 September 2020).

92. National Highway Traffic Safety Administration (NHTSA); Department of Transportation (DOT). 49 CFR Part 563—Event Data Recorders. 2006. Available online: https:/ / www.law.cornell.edu/cfr/text/49/part-563 (accessed on 11 January 2021).

93. Böhm, K.; Kubjatko, T.; Paula, D.; Schweiger, H.G. New developments on EDR (Event Data Recorder) for automated vehicles. Open Eng. 2020, 10, 140-146. [CrossRef]

94. Schmitt, N.; Hofmann, M. Warnverfahren für Eine Hochvolt-Batterie eines Kraftfahrzeugs im Falle eines Unfalls des Kraftfahrzeugs, ein Warnsystem zum Durchführen des Warnverfahrens sowie ein Kraftfahrzeug, das Bestandteile des Warnsystems umfasst. DE 102017 219990 A1. Deutsches Patent- und Markenamt. DPMAregister. 2019. International Patent Application No 102017219990, 9 November 2017.

95. Ellermann Eurocon GmbH, Red Boxx—Der Hochvolt Container zur Bergung von Elektro-Oder Hybridfahrzeugen. Available online: https: / / www.container-ellermann.com/redboxx/ (accessed on 26 November 2020).

96. Paul Müller GmbH, The Müller-Safety-Trailer: The multi-funtion trailer. Available online: https://mueller-safety-trailer.de/en/ (accessed on 26 November 2020).

97. SWISS CAMION, Eine Firebox für E-Unfallautos. Available online: https://www.swisscamion.ch/article/eine-firebox-fuer-eunfallautos / (accessed on 26 November 2020). 